\title{
OPTIMIZATION OF PHYSICAL FITNESS DEVELOPMENT FOR PRIMARY SCHOOL LEARNERS IN PHYSICAL EDUCATION LESSONS
}

\author{
Almagul Ilyasova, Zhanymmurat Erzhanov \\ Kazakh National Pedagogical University after Abay, Almaty, Kazakhstan
}

\begin{abstract}
Background. Nowadays, an urgent social problem in sovereign Kazakhstan, which defines the strategy of social development of our society, is upbringing a new person developed spiritually, morally and physically. Physical fitness of primary school learners as a sphere of scientific-pedagogical knowledge in Kazakhstan Republic has not been fully researched. It conditioned the problem of our investigation - to substantiate theoretically and work out the methodology of optimization of physical fitness development for primary school learners in PE lessons. Theoretical analysis of scientific works suggests that physical fitness of primary school learners as a sphere of scientific-pedagogical knowledge has not been fully investigated. Despite the diversity of issues and theoretical as well as practical pedagogical research, it should be noted that the problem of physical fitness of primary school learners using sport games in PE lessons is still open for theoretical consideration and experimental research.

Research aim was to define the most effective methodology of physical fitness of 8-9 year- old boys in PE lessons using elements of football in general education schools.

Methods. All in all there were 102 boys. They were divided into 4 groups -3 experimental groups and 1 control group. During the experiment, $75 \%$ of time for teaching technical actions of football was devoted for group E1, for E2 $-50 \%$, and for E3 - 25\%; for physical fitness $-25,50$ and $75 \%$ respectively. During the experiment, with the help of methods given above, we covered the following aspects: physical development, general physical fitness, special fitness.

Results. Analyzing the increase in overall physical fitness for the whole period of the experiment, we observed a significant increase in all of the surveyed groups $(\mathrm{p}<.05-.001)$. All the tested groups were approximately of the same level.

Conclusions. The study showed that the best option for physical training for primary school children in physical education classes in comprehensive schools was to have $75 \%$ of the total lesson time to the development of physical fitness and $25 \%$ of the lesson time - to technical training (program C). Physical education classes with elements of football contribute to more intense dynamics of indicators of general and special training of 8-9-year-old boys. Analysis of the studied parameters of fitness and technique of playing football has shown that methods of education and physical qualities of technical preparation, which was given to the third experimental group, contributed to the development of better skills in football.
\end{abstract}

Keywords: physical education lessons, physical, technical fitness, football.

\section{INTRODUCTION}

$\mathrm{N}$ owadays, an urgent social problem in sovereign Kazakhstan, which defines the strategy of social development of our society, is upbringing a new person developed spiritually, morally and physically. Physical education (PE) and sport as an important means of upbringing children have a definite social function and become an element of lifestyle of Kazakh people, creating nice prerequisites for individual development (Кульназарова, 2013). Increasing the importance of systematic PE lessons and sport is carried out by introducing them to all learners, 
which is considered as a condition for preparation of sport reserve and solving other problems of physical development of the young generation (Yang, Telema, Laakgo, Keltikangas-Järvinen, \& Pulli, 2007; Синявский, Власов, \& Сергеев, 2009; Касымбекова, Кошаев, \& Абишев, 2013).

Studying the issues of physical fitness of primary school learners showed that it needed special scientific-pedagogical consideration aimed at working out concrete offers, directed to practical provision of its tasks with physical fitness (Malina, Bouchard, \& Bar-Or, 2004; Бервинова \& Шарабакин, 2005).

Consideration of the problems of physical fitness for primary school learners in PE lessons involves studying:

- The basis of school PE (Минаев, 1989; Волков \& Ромашев, 1998; Бервинова \& Шарабакин, 2005).

- Organization and planning the physical development of pupils in PE lessons and in their leisure time (Гужаловский, 1987; Gudžinskienè, 2006; Юревич \& Мусатаев, 2013).

- Development of skills of schoolchildren (Bar-Or, 1996; Turley, 1997; van Praag, 2000; Бальсевич, 2000).

Theoretical analysis of scientific works suggests that physical fitness of primary school learners as a sphere of scientific-pedagogical knowledge has not been fully investigated. Despite the diversity of issues and theoretical as well as practical pedagogical research, it should be noted that the problem of physical fitness of primary school learners using sport games in PE lessons is still open for theoretical consideration and experimental research.

The relevance of this problem, the lack of theoretical elaboration and demand for practice conditioned the problem of our investigation the development of the theoretical basis and the methodology of optimization of physical fitness of primary school learners in PE lessons.

The aim of the work was to define the most effective methodology for physical fitness of 8-9-year-old boys in PE lessons using the elements of football in general education schools.

\section{METHODS}

Research methods included literature review, pedagogical experiment, testing and methods of mathematical statistics.
Research was carried out in 2011-2012 academic year. Pupils of the $2^{\text {nd }}$ and $3^{\text {rd }}$ grades of general education school "Prestige", Almaty city took part in this investigation. All participants were divided into 4 groups. Three experimental groups (E1, E2, and E3) included 25 boys each, and the control group (C) - 27. All in all there were 102 boys. Physical development of participants who were in the control group was realized according to the program of school general education. For one year the boys in experimental groups E1, E2, E3 in PE lessons did special football exercises for their technical preparation, which was planned on the basis of a modified program of children and youth's sport school (CYSS). Investigations were done in three stages (each of it in 3 months). The first stage of the experiment took place in September-November, the second stage - in December-February, and the third stage - in March-May. The first testing was done in November, the second one - in March, the third one - in June. Effectiveness of two factors was verified during the experiment:

- the ration of time given for physical and technical development;

- purposeful development of various physical skills.

During the experiment, group Elhad program A, i. e. $75 \%$ of lesson time (34 min) was allotted for teaching technical actions of football and $25 \%$ - for the development of physical skills (11 min). Group E2 had program $\mathrm{B}$, where $50 \%$ of lesson time (23 $\mathrm{min}$ ) was devoted to acquiring technical actions, and $50 \%$ of time ( $22 \mathrm{~min}$ ) - for physical skills. Group E3 had program C with $75 \%$ of lesson time (34 min) for physical skills and $25 \%$ of lesson time (11 min) for teaching technical actions of the game.

During the experiment we measured:

- physical characteristics: body height, body mass, circumference of thorax, excursion of thorax;

- general physical fitness: strength of trunk, strength of arm, long jump, $30 \mathrm{~m}$ run, 300 $m$ run, throw of stuffed ball in the sitting position, tapping test for 30 seconds;

- special fitness: hitting the ball for distance, test of agility (running in the gym with changes in $\mathrm{r}$ direction), shuttle run $(3 \times 10 \mathrm{~m})$, hitting five balls to the football gate.

The results obtained were processed by methods of mathematical statistics. We calculated arithmetical mean (X) and standard error (SE), as well as changes in the percentage of the investigated 
data. Comparing the results of definite groups and increase of index sizes for separate periods of research, verifying the hypothesis and equality of separate averages (X) we applied analysis of variance ANOVA (F - Fisher's criteria). Statistical significance of differences between indexes were evaluated by level $\mathrm{p}<.05$ when $\mathrm{F}=2.76$.

\section{RESULTS}

Dynamics of indexes of physical development of the investigated 8-9-year-old pupils is presented in Table 1.

Body height. In the first study, the meaning of this index ranges from 129.5 to $133.3 \mathrm{~cm}$. However, intergroup differences are statistically insignificant $(\mathrm{F}=2.03 ; \mathrm{p}>.05)$. Differences of boys' body height were significant in groups E1 and E3 $(\mathrm{F}=2.86$; $\mathrm{p}<.05$ ). During the second stage of the experiment a further increase of body height on average was $1.03-1.45 \%(\mathrm{p}>.05)$.

Analogues increase of body height of all investigated groups was found in the third group (2.15-2.67\%).

Body mass. In the first study, the average values of this index ranged from 26.7 to $30.4 \mathrm{~kg}$, but intergroup differences were not significant $(F=1.05 ; p>.05)$. The biggest difference of values was between groups E1 and E3 ( $p>.05$ ). During the whole experiment, the sizes of this index increased almost the same in all groups; therefore, in the third investigation statistically significant intergroup differences were not observed $(\mathrm{p}>.05)$.
The circumference of the thorax. In the first survey, the value of this indicator ranged from 62.5 to $65.0 \mathrm{~cm}$, but intergroup differences were not significant $(\mathrm{F}=1.54 ; \mathrm{p}>.05)$. The greatest differences were observed between groups E1 and E2 $(\mathrm{p}<.05)$. During the second phase of the experiment, the values of the chest circumference investigated increased by an average of $0.78-1.28 \%$ $(\mathrm{p}>.05)$, the third $-2.04-2.52(\mathrm{p}>.05)$.

Excursion of the thorax. Throughout the experiment, there was a significant increase in this index in all groups. The most significant increase was noted in groups E2 and E3.

Changes in general physical fitness are presented in Table 2.

$30 \mathrm{~m}$ run. The initial results of this index were almost equal in all groups $(p>.05)$. In the second survey, group differences were not observed $(p>.05)$. It should be noted that during the second stage of the research the value of this indicator improved to the greatest extent in the experimental groups (on average from 4.86 to $6.62 \%, \mathrm{p}<.01$ ), some lower growth was observed in the control group $(3.32 \%, \mathrm{p}<.05)$. In the third survey, results ranged on average from 5.6 to 5.5. The most results in E2 group, which spend more time for the development of physical skills, produced insignificant differences $(\mathrm{F}=0.48 ; \mathrm{p}>.05)$.

Long jump from the standing position. In the first survey, the results of this measure were almost identical to intergroup differences which were statistically insignificant $(\mathrm{F}=1.48 ; \mathrm{p}>.05)$. The greatest differences were observed between the

Table 1. Changes in the physical development of the tested groups $(\mathrm{X} \pm \mathrm{SE})$

\begin{tabular}{|c|c|c|c|c|c|}
\hline \multirow{2}{*}{ Index } & \multirow{2}{*}{ Stages } & \multicolumn{4}{|c|}{ Groups } \\
\hline & & $\mathbf{E}_{1}$ & $\mathbf{E}_{2}$ & $\mathbf{E}_{3}$ & C \\
\hline $\begin{array}{l}\text { Body height } \\
(\mathrm{cm})\end{array}$ & $\begin{array}{l}1 \\
2 \\
3\end{array}$ & $\begin{array}{l}133.3 \pm 1.00 \\
135.7 \pm 1.04 \\
139.6 \pm 1.11\end{array}$ & $\begin{array}{l}131.7 \pm 1.32 \\
134.4 \pm 1.43 \\
137.8 \pm 1.55\end{array}$ & $\begin{array}{l}129.5 \pm 0.93 \\
131.9 \pm 0.99 \\
136.4 \pm 1.09\end{array}$ & $\begin{array}{l}131.9 \pm 1.37 \\
134.3 \pm 1.43 \\
138.6 \pm 1.67\end{array}$ \\
\hline $\begin{array}{l}\text { Body mass } \\
(\mathrm{kg})\end{array}$ & $\begin{array}{l}1 \\
2 \\
3\end{array}$ & $\begin{array}{l}30.4 \pm 1.00 \\
31.5 \pm 1.06 \\
33.8 \pm 1.11\end{array}$ & $\begin{array}{c}28.3 \pm 0.81 \\
29.3 \pm 0.82 \\
31.2 \pm 0.89\end{array}$ & $\begin{array}{l}26.7 \pm 0.92 \\
29.9 \pm 0.92 \\
32.2 \pm 0.99\end{array}$ & $\begin{array}{l}28.9 \pm 0.70 \\
29.7 \pm 0.71 \\
31.8 \pm 0.73\end{array}$ \\
\hline $\begin{array}{l}\text { Circumference of the } \\
\text { thorax } \\
(\mathrm{cm})\end{array}$ & $\begin{array}{l}1 \\
2 \\
3\end{array}$ & $\begin{array}{l}65.0 \pm 1.00 \\
66.2 \pm 0.98 \\
68.6 \pm 1.04\end{array}$ & $\begin{array}{l}62.5 \pm 0.63 \\
63.4 \pm 0.59 \\
65.8 \pm 0.62\end{array}$ & $\begin{array}{l}63.7 \pm 0.86 \\
64.6 \pm 0.89 \\
66.8 \pm 1.05\end{array}$ & $\begin{array}{l}63.8 \pm 0.66 \\
64.3 \pm 0.68 \\
66.0 \pm 0.69\end{array}$ \\
\hline $\begin{array}{l}\text { Excursion of the thorax } \\
(\mathrm{cm})\end{array}$ & $\begin{array}{l}1 \\
2 \\
3\end{array}$ & $\begin{array}{l}3.6 \pm 0.22 \\
3.8 \pm 0.21 \\
4.9 \pm 0.20\end{array}$ & $\begin{array}{l}3.1 \pm 0.24 \\
3.6 \pm 0.20 \\
5.3 \pm 0.18\end{array}$ & $\begin{array}{l}3.7 \pm 0.24 \\
4.2 \pm 0.23 \\
5.6 \pm 0.21\end{array}$ & $\begin{array}{l}4.6 \pm 0.22 \\
4.8 \pm 0.23 \\
6.2 \pm 0.31\end{array}$ \\
\hline
\end{tabular}


groups E2 and E3 $(F=1.8 ; p>.05)$ and the smallest between groups E1 and E3 $(F=0.05 ; p>.05)$. During the second phase of the experiment, results of the long jump increased by $10.4-15.1 \mathrm{~cm}$ on average. In the third survey, results of this indicator ranged from 156.0 to $159.2 \mathrm{~cm}$, but intergroup differences were not statistically significant $(\mathrm{F}=$ $0.24 ; \mathrm{p}>.05)$. The greatest differences were observed between E1 and E2 we all as E2 and E3 groups (accordingly: $\mathrm{F}=1.69 ; \mathrm{p}>.05 ; \mathrm{F}=1.7 ; \mathrm{p}>$ $.05)$, and the smallest - between E1 and E3 groups $(\mathrm{F}=1.11 ; \mathrm{p}>.05)$. The most significant increase was observed in the results of E3 group.

Throwing the medicine ball while sitting. Initial values of this index ranged from 194.7 to $236.6 \mathrm{~cm}$, and intergroup differences were statistically significant $(\mathrm{F}=3.58 ; \mathrm{p}<.05)$. The greatest differences were observed between the E2 and $\mathrm{C}$ groups $(\mathrm{F}=2.83 ; \mathrm{p}<.05)$. In the second survey, intergroup differences of this indicator were also statistically significant $(F=3.18 ; p<$ $.05)$. In the third survey, results this index ranged from $256.8 \mathrm{~cm}$ in C group to $307.6 \mathrm{~cm}$ in $\mathrm{E} 1$ group, intergroup difference was statistically significant $(\mathrm{F}=4.24 ; \mathrm{p}>.01)$. The greatest difference was betweenE1 and $\mathrm{C}$ groups $(\mathrm{F}=2.9 ; \mathrm{p}>.05)$, and the smallest - between E1 and E2 groups, E3 and $\mathrm{C}$ groups (accordingly $\mathrm{F}=1.13 ; \mathrm{F}=1.11 ; \mathrm{p}>.05$ ).

The rise in the saddle. Initial results of this indicator ranged from 4 to 10 times, intergroup differences statistically significant $(\mathrm{F}=7.7 ; \mathrm{p}<$ $.001)$. The greatest difference was between groups $\mathrm{E} 2$ and $\mathrm{C}(\mathrm{F}=4.7 ; \mathrm{p}<.01)$ and the smallest difference - between E1 and E3groups $(F=1.65$; $\mathrm{p}>.05)$. In the third survey, the indicator values ranged from 11 in group $\mathrm{C}$ to 17 times in group $\mathrm{E} 3(\mathrm{~F}=13.1 ; \mathrm{p}<.001)$. The greatest difference in indicators was between groups $\mathrm{E} 3$ and $\mathrm{C}(\mathrm{p}<.05)$

$300 \mathbf{m}$ run. In the first survey, results of this indicator in the experimental groups ranged from 79.1 to $73.9 \mathrm{~s}$, however, intergroup differences were insignificant $(\mathrm{F}=2.05 ; \mathrm{p}>.05)$.

In the second phase of the research, performance in races for 300 meters improved on average by $4.01-8.56 \%$. In the third survey we observed opposite results, so intergroup differences were again statistically insignificant $(\mathrm{F}=2.35 ; \mathrm{p}<.05)$, the exception is a significant difference between groups $\mathrm{E} 1$ and $\mathrm{C}(\mathrm{F}=3.10 ; \mathrm{p}<.05)$. The most significant improvement was seen in the group E3 - 8.9s.
Tapping Test. Initial values of this indicator ranged from 48 to 54 movements, intergroup differences were statistically significant $(\mathrm{F}=5.28$; $\mathrm{p}<.01)$. The biggest difference was seen between groups $\mathrm{E} 2$ and $\mathrm{C}(\mathrm{F}=3.53 ; \mathrm{p}<.05)$, and the smallest - between groups E1 and E2 ( $\mathrm{F}=1.12$; $p>.05)$. In the third investigation, tapping test results ranged from 58 to 67 movements, intergroup differences were again statistically significant $(\mathrm{F}=$ $6.78 ; \mathrm{p}<.01)$. The most significantly these indexes were in groups E2 and E3.

Trunk force. The initial results of this indicator fluctuated from $38.4 \mathrm{~kg}$ in group $\mathrm{C}$ to $52.7 \mathrm{~kg}$ in group E2, intergroup differences were statistically significant $(\mathrm{F}=6.15 ; \mathrm{p}<.001)$. During the following investigations intergroup differences of results were statistically significant $(p<.001)$.

In the second stage, this index increased most in group $\mathrm{E}_{3}$. In groups $\mathrm{E} 1$ and $\mathrm{E} 2$ backbone force increased insignificantly $(p>.05)$, in $E_{3}$ group it increased by $14.6 \%(\mathrm{p}<.05)$. In the latest investigation, results of this indicator fluctuated from 47.4 to $60.2 \mathrm{~kg}$, and intergroup differences were statistically significant $(F=9.72 ; p<.001)$.

Arm force. In the first investigation the results of this index fluctuated from 11.9 to $12.9 \mathrm{~kg}$, however intergroup differences remained insignificant $(\mathrm{F}=$ $0.45 ; p>.05)$. In the subsequent stages of research there was practically an identical increase in this index in all groups with some advantage of group E3, where we noticed a significant increase of results $(\mathrm{p}<.05)$ in all stages.

In the third investigation intergroup differences of results of arm force were statistically significant $(\mathrm{F}=3.07 ; \mathrm{p}<.05)$. Most differences were observed between groups $\mathrm{C}$ and $\mathrm{E} 3(\mathrm{~F}=3.19 ; \mathrm{p}<.05)$, and the least - between groups $\mathrm{E} 1$ and $\mathrm{C}(\mathrm{F}=0.45$; $\mathrm{p}>.05)$.

The changes of indexes of special physical fitness are presented in Table 3.

Shuttle run. At the beginning of experiment results of this index fluctuate from 10.9 to $9.7 \mathrm{~s}$. During the second stage, in all groups the results of this index were stable $(p>.05)$. In the last investigation, results of shuttle run fluctuated from 9.3 to $8.4 \mathrm{~s}$. Most differences were observed between groups $\mathrm{E} 2$ and $\mathrm{C}(\mathrm{F}=4.37 ; \mathrm{p}<.01)$, and the least - between groups E1 and E3 $(\mathrm{F}=1.66$; $\mathrm{p}>.05)$.

Test of agility. In the first investigation, results of this index fluctuated from 31.9 to $29.4 \mathrm{~s}$. 
Table 2. Changes of indexes of general physical fitness $(\mathrm{X} \pm \mathrm{SE})$

\begin{tabular}{|c|c|c|c|c|c|}
\hline \multirow{2}{*}{ Indexes } & \multirow{2}{*}{ Stages } & \multicolumn{4}{|c|}{ Groups } \\
\hline & & $\mathbf{E}_{1}$ & $\mathbf{E}_{2}$ & $\mathbf{E}_{3}$ & $\mathrm{C}$ \\
\hline $30 \mathrm{~m}$ run $(\mathrm{s})$ & $\begin{array}{l}1 \\
2 \\
3\end{array}$ & $\begin{array}{l}6.1 \pm 0.09 \\
5.7 \pm 0.07 \\
5.6 \pm 0.08\end{array}$ & $\begin{array}{c}6.1 \pm 0.10 \\
5.6 \pm 0.7 \\
5.5 \pm 0.06\end{array}$ & $\begin{array}{l}6.3 \pm 0.11 \\
5.7 \pm 0.07 \\
5.5 \pm 0.05\end{array}$ & $\begin{array}{l}6.1 \pm 0.14 \\
5.8 \pm 0.12 \\
5.6 \pm 0.11\end{array}$ \\
\hline $\begin{array}{l}\text { Long jump from the } \\
\text { standing position }(\mathrm{cm})\end{array}$ & $\begin{array}{l}1 \\
2 \\
3\end{array}$ & $\begin{array}{l}130.4 \pm 3.62 \\
145.5 \pm 2.66 \\
156.8 \pm 2.73\end{array}$ & $\begin{array}{l}140.3 \pm 4.30 \\
153.9 \pm 4.09 \\
159.2 \pm 3.84\end{array}$ & $\begin{array}{l}130.1 \pm 3.28 \\
140.5 \pm 2.72 \\
156.0 \pm 3.46\end{array}$ & $\begin{array}{l}133.3 \pm 4.06 \\
142.0 \pm 4.17 \\
156.8 \pm 3.51\end{array}$ \\
\hline $\begin{array}{l}\text { Throwing the medicine } \\
\text { ball }(\mathrm{cm})\end{array}$ & $\begin{array}{l}1 \\
2 \\
3\end{array}$ & $\begin{array}{c}233.0 \pm 10.56 \\
254.3 \pm 9.98 \\
307.6 \pm 12.11\end{array}$ & $\begin{array}{l}236.6 \pm 8.36 \\
255.4 \pm 8.34 \\
288.6 \pm 9.73\end{array}$ & $\begin{array}{l}210.7 \pm 7.46 \\
227.3 \pm 6.97 \\
272.5 \pm 8.65\end{array}$ & $\begin{array}{l}194.7 \pm 13.16 \\
214.1 \pm 11.92 \\
256.8 \pm 10.38\end{array}$ \\
\hline $\begin{array}{l}\text { The rise in the saddle } \\
\text { (quantity) }\end{array}$ & $\begin{array}{l}1 \\
2 \\
3\end{array}$ & $\begin{array}{c}8 \pm 0.63 \\
13 \pm 0.55 \\
15 \pm 0.39\end{array}$ & $\begin{array}{l}11 \pm 0.84 \\
14 \pm 0.63 \\
16 \pm 0.72\end{array}$ & $\begin{array}{c}9 \pm 1.05 \\
14 \pm 0.79 \\
17 \pm 0.75\end{array}$ & $\begin{array}{c}4 \pm 0.86 \\
7 \pm 0.89 \\
11 \pm 0.90\end{array}$ \\
\hline $300 \mathrm{~m}$ run $(\mathrm{s})$ & $\begin{array}{l}1 \\
2 \\
3\end{array}$ & $\begin{array}{l}74.5 \pm 1.29 \\
68.1 \pm 1.08 \\
65.8 \pm 1.27\end{array}$ & $\begin{array}{l}73.9 \pm 1.24 \\
68.9 \pm 1.11 \\
67.3 \pm 1.18\end{array}$ & $\begin{array}{l}79.1 \pm 2.07 \\
74.1 \pm 1.72 \\
70.2 \pm 1.79\end{array}$ & $\begin{array}{l}75.4 \pm 1.30 \\
72.4 \pm 1.25 \\
70.2 \pm 1.65\end{array}$ \\
\hline $\begin{array}{l}\text { Tapping Test (number of } \\
\text { times in } 10 \mathrm{~s} \text { ) }\end{array}$ & $\begin{array}{l}1 \\
2 \\
3\end{array}$ & $\begin{array}{l}53 \pm 2.66 \\
60 \pm 1.60 \\
66 \pm 1.48\end{array}$ & $\begin{array}{l}54 \pm 2.58 \\
62 \pm 1.63 \\
67 \pm 0.91\end{array}$ & $\begin{array}{l}50 \pm 1.67 \\
58 \pm 1.09 \\
63 \pm 0.98\end{array}$ & $\begin{array}{l}48 \pm 2.19 \\
52 \pm 1.26 \\
58 \pm 1.32\end{array}$ \\
\hline Trunk strength (kg) & $\begin{array}{l}1 \\
2 \\
3\end{array}$ & $\begin{array}{l}46.6 \pm 2.37 \\
54.1 \pm 1.41 \\
56.8 \pm 1.45\end{array}$ & $\begin{array}{l}52.7 \pm 1.53 \\
56.7 \pm 1.43 \\
58.7 \pm 1.45\end{array}$ & $\begin{array}{l}46.9 \pm 1.81 \\
54.9 \pm 1.49 \\
60.2 \pm 1.36\end{array}$ & $\begin{array}{l}38.4 \pm 2.80 \\
41.5 \pm 2.79 \\
47.4 \pm 2.71\end{array}$ \\
\hline Arm strength (kg) & $\begin{array}{l}1 \\
2 \\
3\end{array}$ & $\begin{array}{l}12.9 \pm 0.74 \\
17.8 \pm 0.66 \\
20.3 \pm 0.59\end{array}$ & $\begin{array}{l}11.9 \pm 0.70 \\
16.3 \pm 0.67 \\
18.9 \pm 0.54\end{array}$ & $\begin{array}{l}12.9 \pm 0.69 \\
17.0 \pm 0.71 \\
21.8 \pm 0.89\end{array}$ & $\begin{array}{l}12.6 \pm 0.69 \\
16.4 \pm 0.49 \\
20.8 \pm 0.63\end{array}$ \\
\hline
\end{tabular}

However, intergroup differences were statistically insignificant $(\mathrm{F}=1.14 ; \mathrm{p}>.05)$. In the third investigation, results of complex agility fluctuated from 26.4 to $22.4 \mathrm{~s}$, intergroup differences were statistically significant $(\mathrm{F}=4.92 ; \mathrm{p}<.01)$. The improvement of result of this test was most considerable for representatives of group E3 (by $28.4 \%)$. Most differences were observed in groups $\mathrm{E} 1$ and $\mathrm{C}(\mathrm{F}=3.92 ; \mathrm{p}<.05)$ and smallest - between groups $\mathrm{E} 1$ and $\mathrm{E} 3(\mathrm{~F}=2.0 ; \mathrm{p}>.05)$.

Hitting of ball for distance. At the beginning of the research, results of this index increased from 8.2 to $10.3 \mathrm{~m}$, however intergroup differences were statistically insignificant $(\mathrm{F}=0.94 ; \mathrm{p}>.05)$. In the second investigation, intergroup differences in this index fluctuated statistically significantly $(p<.001)$. In the third investigation, results of this index fluctuated from 17.5 to $21.4 \mathrm{~m}$, intergroup differences were statistically significant $(\mathrm{F}=3.84$; $\mathrm{p}<.05)$. During the third stage of the research the value of this index increased in groups E1-E3 and $\mathrm{C}$, respectively by $78.6 ; 72.4 ; 85.3$ and $37.3 \%$. The greatest difference of indexes could be seen between groups $\mathrm{E} 1$ and $\mathrm{C}(\mathrm{F}=1.39 ; \mathrm{p}<.05)$, the smallest - between groups E2 and E2 ( F = 1.2; $\mathrm{p}>.05)$.
Hitting five balls to the football gate. At the beginning of research, results of this index fluctuated from 16.6 to $12.9 \mathrm{~s}$. The greatest difference was between groups $\mathrm{E} 1$ and $\mathrm{C}(\mathrm{F}=4.54$; $\mathrm{p}<.01$ ), the smallest - between groups E1 and E2 $(\mathrm{F}=1.39 ; \mathrm{p}>.05)$. In the second survey, intergroup index differences were statistically significant. The subjects of experimental groups got the highest indexes. In the third survey, the results of this index fluctuated from 12.3 to $10.3 \mathrm{~s}$, intergroup differences were statistically significant $(\mathrm{F}=$ 5.77; $\mathrm{p}<.01)$. The highest difference was between groups $\mathrm{E} 3$ and $\mathrm{C}(\mathrm{F}=3.75 ; \mathrm{p}<.05)$, the smallest was between groups E1 and E2 $(F=1.16 ; p>.05)$.

During the experiment, at the physical education lessons, in the time allotted for technical preparation, boys were trained by following techniques of football game: dribble, taking the ball, stop the ball, hitting the ball with the foot and head, deceptive motion. The received data testified that learning limited had a positive impact on pupils' technical preparation indexes, that was confirmed by the recorded data on the implementation of correct hits, stops and ball transmission. 
Table 3. The results of specially prepared index $(X \pm \mathbf{S x})$

\begin{tabular}{|c|c|c|c|c|c|}
\hline \multirow{2}{*}{ Data } & \multirow{2}{*}{ Stages } & \multicolumn{4}{|c|}{ Groups } \\
\hline & & $\mathbf{E}_{1}$ & $\mathbf{E}_{2}$ & $\mathbf{E}_{3}$ & $\mathrm{C}$ \\
\hline Shuttle run (s) & $\begin{array}{l}1 \\
2 \\
3\end{array}$ & $\begin{array}{c}10.1 \pm 0.17 \\
9.8 \pm 0.17 \\
8.7 \pm 0.13\end{array}$ & $\begin{array}{l}9.7 \pm 0.21 \\
9.3 \pm 0.16 \\
8.4 \pm 0.14\end{array}$ & $\begin{array}{c}10.2 \pm 0.24 \\
9.6 \pm 0.14 \\
8.8 \pm 0.14\end{array}$ & $\begin{array}{c}10.9 \pm 0.17 \\
10.5 \pm 0.17 \\
9.3 \pm 0.13\end{array}$ \\
\hline Test of agility (s) & $\begin{array}{l}1 \\
2 \\
3\end{array}$ & $\begin{array}{l}30.6 \pm 1.02 \\
25.2 \pm 0.61 \\
22.4 \pm 1.03\end{array}$ & $\begin{array}{l}29.4 \pm 0.77 \\
24.9 \pm 0.70 \\
23.3 \pm 0.16\end{array}$ & $\begin{array}{l}31.7 \pm 0.95 \\
27.2 \pm 0.45 \\
22.7 \pm 0.59\end{array}$ & $\begin{array}{l}31.9 \pm 1.07 \\
29.3 \pm 1.02 \\
26.4 \pm 1.14\end{array}$ \\
\hline $\begin{array}{l}\text { Hitting of ball for } \\
\text { distance }(\mathrm{m})\end{array}$ & $\begin{array}{l}1 \\
2 \\
3\end{array}$ & $\begin{array}{l}10.3 \pm 0.96 \\
18.4 \pm 0.79 \\
21.4 \pm 0.74\end{array}$ & $\begin{array}{c}9.8 \pm 1.12 \\
16.9 \pm 0.84 \\
21.3 \pm 1.01\end{array}$ & $\begin{array}{c}8.2 \pm 0.96 \\
15.2 \pm 1.13 \\
19.3 \pm 0.99\end{array}$ & $\begin{array}{c}9.1 \pm 0.71 \\
12.5 \pm 0.71 \\
17.5 \pm 0.95\end{array}$ \\
\hline $\begin{array}{l}\text { Hitting five balls to the } \\
\text { football gate (s) }\end{array}$ & $\begin{array}{l}1 \\
2 \\
3\end{array}$ & $\begin{array}{l}12.9 \pm 0.41 \\
11.6 \pm 0.33 \\
10.9 \pm 0.32\end{array}$ & $\begin{array}{c}1.7 \pm 0.37 \\
11.8 \pm 0.28 \\
10.8 \pm 0.14\end{array}$ & $\begin{array}{l}14.2 \pm 0.51 \\
11.5 \pm 0.35 \\
10.3 \pm 0.29\end{array}$ & $\begin{array}{l}16.6 \pm 0.76 \\
14.9 \pm 0.75 \\
12.3 \pm 0.45\end{array}$ \\
\hline
\end{tabular}

\section{DISCUSSION}

Analyzing the dynamics of the physical development of children of primary school age, during the experimental work we did not see much difference between the experimental and control groups. Studies indicate that children develop without abnormalities. This is one of the main requirements for physical exercise (Baxter-Jones, 2001). Meanwhile, comparing the average physical development of the first and third surveys, we observed a slightly larger increase of indexes in the experimental groups, and especially in the second and the third. This can be explained by the fact that the means and methods used with large amounts of physical training in teaching boys of experimental groups had a positive impact on their physical development, in contrast to the control group. The analysis showed that data on physical development did not fully disclose the physical condition of the child. The main signs of physical fitness of children still were well-developed strength, speed, endurance, joint mobility, coordination and agility (Bar-Or, 1996; Armstrong \& Welsman, 2000; Telema, Yang, Hirvansalo, \& Raitkari, 2006; Rowland, 2007)

Analysis of the dynamics of general physical fitness results shows that in all groups surveyed there was a noticeable increase in the values of their parameters. This indicates a favorable age of 8-9 years for the development of basic motor skills: speed, strength, endurance. On this issue similar opinion is shared by many other authors. (Волков \& Ромашев, 1998; Rowland, 2005;
Dencer, Thorsson, \& Karlson, 2009; Синявский et al., 2009).

These data of basic physical fitness of the first stage of the study indicate the different relationship between the indexes of the groups. For example, in the run for 30 meters, the long jump, hand grip strength, no real differences were seen $(p>.05)$. However, it should be noted that the growth of these indexes was somewhat higher in the experimental groups. Indicators of the tapping test, abdominal muscles, postural forces were interrelated statistically significantly $(p<.01)$ throughout the first phase. Here we should note the similarity of this opinion with the opinion of well-known scientists Гужаловский (1987), van Praag (2000), Stepinski, Zwirko, Frolkiewicz and Debieka, (2003), Malina et al. (2004).

According to the analysis of the first phase results it should be noted that in general ther was some advantage of groups E1 and E3. This can be explained by the fact that a large part of the lesson was assigned to the development of physical skills. Meanwhile, in group E1 greater emphasis was on teaching the techniques of football, and the control group was engaged in a school program.

During the experiment, a similar pattern was observed during the second phase of the experiment. Increase in overall physical training was more intense in groups E2 and E3.

This is especially shown by indicators of throwing the soft ball, running for 300 meters, the long jump where already significant differences 
were found between the averages of the tested groups. In general, the second stage of the study showed the advantages of experimental groups over the control group. Thus, all this shows the usefulness of the techniques used in the experimental groups during the study period.

During the third phase of the study parameters of physical training in all tested groups increased significantly. However, it should be noted that the greatest index gains were achieved group E3 in the third stage. It can be explained by the fact that they were given more time $(75 \%)$ of the lesson on the development of physical skills.

Analyzing the performance of special training throughout the experiment in the tested groups we see the following pattern: in terms of skill set, operational thinking, the impact on range, experimental groups were leading. This can be explained by the fact that these results depend not only on the level of the manifestation of powerspeed, but also on the quality of the technique of movement. The same opinion is held by the researchers Dencer et al. (2006), Chvicialovskij, Wulf, de Medeiros, Kalfer and Tani (2008), Jaščaninienè, Kemerytė-Riaubienè, Kepežènas and Katinas (2011).

Under the influence of purposeful physical training in the secondary school boys learned the basic techniques of football. The experimental data showed that for the qualitative development of the techniques of football in the first place good physical preparation is required. This is evident in the third experimental group, where the first stage of the experimental education of physical skills received $75 \%$ of the lesson time.

All studies of physical development, general and specialized training of primary school children show availability of application of the integrated program with elements of football (the experimental groups) in the classroom with the 8-9 year- old boys without harm to their health.

Data from studies indicate that training with elements of football create more favorable conditions for the manifestation of its features for more children in football. This coincides with the opinion of Адамбеков and Боранбаев (1999).

The data on the technical training, after each stage and at the end of the experiment show that pupils of the experimental groups mastered the techniques of football. This is evidenced by the fact that 13 boys from the experimental groups were taken to the football school (one of the first group, 4 - from the second, 8 - from the third)

Our data suggest that the initial training was appropriate to establish a foundation for general physical fitness. It would be possible to achieve better results and special technical preparation, as confirmed by the data obtained in the third experimental group.

\section{CONCLUSIONS}

1. Analyzing the increase in overall physical fitness for the whole period of the experiment, we see a significant increase in all of the surveyed groups $(\mathrm{p}<.05-.001)$. All tested groups were approximately of the same level. Indicators of general physical fitness could be divided into two groups:

- the first group included indicators which showed superiority of the experimental groups: $30 \mathrm{~m}$ run, $300 \mathrm{~m}$ run, long jump, taping test $(\mathrm{p}<.05-.01)$;

- the second group included indicators that showed approximate equality between all groups: throwing a soft ball while sitting, strength of spine muscles, training of the abdominal muscles, force of the hand $(\mathrm{p}<.01-.01)$.

2. The study showed that the best option for physical training of primary school children in physical education classes at comprehensive schools should be considered when $75 \%$ of the total lesson time was given to physical fitness and $25 \%$ of the time the lesson was given technical training (program C).

3. Physical education classes with elements of football contribute to more intense dynamics of indicators of general and special training of 8-9-year-old boys.

4. Analysis of the studied parameters of fitness and techniques of playing football has shown that methods of education and physical qualities of technical preparation that were given to the third experimental group contributed to the formation of more successful elements of football.

General increase of indicators of technical preparation of the 8-9-year-old boys, evaluated by the expert commission was as follows: in group E1 $-38.8 \%$, in group E2 $-41.2 \%$, in group C $26.6 \%$. 


\section{REFERENCES}

Armstrong, N., \& Welsman, J. (2000). Development of aerobic fitness during childhood and adolescence. Pediatric Exercise Science, 12, 128-140.

Bar-Or, O. (1996). The child and adolescent athlete. Blackwell Science.

Baxter-Jones, A. (2001). Growth and development of young athletes. Sport Medicine, 4, 59-64.

Chvicialovskij, S., Wulf, G., de Medeiros, F., Kalfer, A., \& Tani, G. (2008). Learning benefits of self-controlled knowledge of results in 10 year old. Research Quarterly for Exercise and Sports, 79(3), 405-410.

Dencer, M., Thorsson, D., \& Karlson, M. (2006). Daily physical activity in Swedish children aged 8-11 years. Scandinavian Journal of Medicine and Science in Sports, 16, 252-257.

Gudžinskienè, V. (2006). Physical activity of primary schoolchildren and factors determining their physical activity. Sport Science (in Lithuanian), 4(46), 55-60.

Jaščaninienė, N., Kemerytė-Riaubienè, E., Kepežènas, A., \&Katinas, M. (2011). The effect of systematic football training on some respiratory system indices of 11 year old children. Sport Science (in Lithuanian), 2(64), 54-58.

Malina, R. M., Bouchard, C., \& Bar-Or, O. (2004.) Growth, maturation and physical activity. Champaign, IL: Human Kinetics.

van Praag, E. (2000). Development of anaerobic function during childhood and adolescence. Pediatric Exercise Science, 12, 150-173.

Rowland, T. W. (2007). Evaluation of maximal oxygen uptake of children. Medicine and Sport Science, 50, 200-209.

Rowland, T. (2007). Physical activity, fitness and children. Physical activity and health. Champaign, IL: Human Kinetics.

Stepinski, M., Zwirko, T., Frolkiewicz, B., \& Debieka, J. (2003). The level of motor abilities of 10-13 year old soccer players. Journal of Human Kinetics, 9, 99-109.

Telema, R., Yang, X., Hirvansalo, M., \& Raitkari, O. (2006). Participation in organized youth sport as a predictor of adult physical activity: A 21-year longitudinal study. Pediatric Exercise Science, 17, 76-78.

Turley, K. R. (1997). Cardiovascular responses to exercise in children. Sports Medicine, 24(4), 241-257.

Yang, X., Telema, R., Laakgo, L., KeltikangasJärvinen, L., \& Pullli, L. (2007). Determination of adult physical activity: Relative importance of youth physical activity and demographic, psychological, behavioral and environmental factors on adulthood. Acta Kinesiologiae Universtatis Tartuensis, 12, 129-146.

Адамбеков, К. И., \& Боранбаев, К. С. (1999). Совершенствование скоростных качеств у юных футболистов с использованием эффективных средств и методов тренировки. Теория и практика Казахстанского футбола, 2, 41-47.

Бальсевич, В. К. (2000). Онтокинезиология человека. Москва: ФиС. С. 68-71.

Бервинова, Н. С., \& Шарабакин, Н. И. (2005). Основы школьной физической культуры: учебник для студентов физкультурньх вузов, учителей и тренеров спортивных школ. Бишкек.

Волков, В. Н., \& Ромашев, А. В. (1998). Лонгитудинальные исследования скоростносиловых показателей школьников 11-14 лет. Теория и практика физической культуры, 7, 5-6.

Гужаловский, А. А. (1987). Физическое воспитание школьников: критические периоды развития. Теория и практика физической культуры, 7, 37-39.

Касымбекова, С., Кошаев, М. Н., \& Абишев, А. Р. (2013). Физическое воспитание учащейся молодежи в системе образования республики Казахстан: материалы международной конференции “Проблемы и перспективы физической культуры в современном обществе", Алматы, Каз. НПУ (сс. 70-72).

Кульназарова, А. К. (2013). Перспективы направления совершенствования физкультурно-спортивного движения в республике Казахстан в период до 2022 года. Материалы международной конференции "Проблемы и перспективы физической культуpы в современном обществе", Алматы, Каз. НПУ. c. $4-8$.

Минаев, В. Н. (1989). Основы методики физического воспитания школьников. Москва. ФиС.

Синявский, Н. И., Власов В. В., \& Сергеев К. В. (2009). Мониторинг физической подготовленности детей младшего школьного возраста среднего прибья. Физическая культура: воспитание, образование, тренировка, 3, 31-32.

Юревич, А. И., \& Мусатаев, К. Б. (2013). Концепция развития детско-юношеского футбола в Казахстане. Материалы международной конференции "Проблемь и перспективы физической культуpы в современном обществе”, Алматы, Каз. НПУ. c. 34-36.
Corresponding author Almagul Ilyasova

Kazakh National Pedagogical University after Abay

Spartak Stadium, Omarovast., Almaty

Kazakhstan

Tel +7(775) 5717180

E-mail timfk.2013@mail.ru 